Ewa Gacka, Ph.D.

Laboratory of Special Education

Faculty of Educational Sciences

University of Lodz, 91-433 Łódź, Smugowa 10/12

Poland

\title{
TRENDS IN DEVELOPMENT OF SPEECH-LANGUAGE CARE VERSUS SOCIO-DEMOGRAPHIC CHANGES
}

\section{Introduction}

Linguistic communication disorders and the ways of their treatment, as well as prophylactic measures to prevent irregularities of speech constitute the subject of speech-language therapy. L. Kaczmarek, the Polish founder of modern speech therapy, to its area also included the culture of the spoken word: colloquial, journalistic, and artistic (1988). The subject of speech therapy influence is a human being from birth to old age, which is consistent with contemporary speech recognition as a sum of competencies and skills, evolving from birth (Grabias, 2002). Speech, being the same as the verbal communication or linguistic communication is not only a realization of sounds, but a complex function which consists of the creation of spoken utterances, i.e. speaking and reception of verbal expressions or understanding (Kaczmarek, 1988). This is possible due to skills and competences. The need to communicate is one of the basic human needs which applies to individuals from birth to the end of their natural life. Hence, any abnormalities associated with speech impinge adversely on human functioning. The perception of speech in terms of needs is linked to the quality of life. The quality of life is a concept that is particularly relevant in teaching, medical and social sciences. Although the subject of interest in speech therapy is a person with impaired verbal communication throughout the entire life, this science is commonly identified with correction of speech faults (articulation), most often in children as late as in their preschool age, and understanding of speech-language care is limited to this category of its recipients. As an academic discipline, speech-language therapy has been developing in Poland since the 1960's, but its roots go back to the early nineteenth century, when J. Siestrzyński developed his own method of working with people with 
hearing loss, using the hand-oral signs (Kaczmarek, 1969). Although most of the work of the speech therapy precursors was dedicated to children, the need to help adult people with speech disorders was already perceived and speech disorders in adults were the point of interest. Even before World War II, J. Szmurło in association with B. Dylewski led to the formation of the facility for adults with impaired linguistic communication in Vilnius (Dylewski, 1947/1948). In the 20's and 30's of the twentieth century, in Katowice, the priest S. Wilczewski not only practiced therapy towards people with impaired speech, but also organized speech hygiene courses in teaching and religious seminaries (Chęciek, Nowakowska - Kempna, 1996). The institution which also accepted adults with speech disorders was the Warsaw Institute for the Aberrations of Speech and Sufferings of Nasopharyngeal Cavity for Permanent and Incoming Patients run by W. Ołtuszewski founded in 1880 (originally called the House of Health) (Demelowa, 1975).

Properly organized system of speech care is important for robust and efficient development of speech therapy practices covering the entire human lifespan. Adequate speech care organization allows for the recognition and fulfillment of the needs of people with impaired verbal communication. In order to achieve this, it is helpful to analyze the demographic and social changes which can help identify groups of potential recipients of speech therapy services. The ongoing socio-demographic transformations and dynamic development of medical science require identification not so much of new areas of speech therapy interests but of a different distribution of forces and drawing attention to the need to intensify the interaction in certain areas. The paper will be devoted to this particular subject.

\section{The Importance of Speech in Human Life}

Man is a social being, and the need to communicate is one of the basic needs. The development of the individual takes place through interpersonal relationships, and they are conditioned by the possibilities of communication. Most living organisms tend to form some type of communication, a language, but only a human being is capable of using the language in a "significant" way (Aitchison, 1991). Language, on the other hand, is one of the elements of speech (Kaczmarek, 1988). Communication is a type of human behavior that occurs among its participants (sender and receiver) in a particular situation. The sender provides the information, opinions, feelings, beliefs, etc., in order to inform and influence the thinking and behavior of the recipient (Gajda, 2003). L. Kaczmarek distinguishes two ways of communication: nonlinguistic and linguistic, and the linguistic communication includes: verbal, written and signaling (1988). Verbal linguistic communication, or language communication can be equated with speech. Speech is the feature that distinguishes the human being from the rest of the natural world, testifying to its 
uniqueness. Speech allows the human being to be fulfilled, determines the full development of his/her personality and allows for satisfactory functioning among the peers.

L. Kaczmarek, defining speech in social terms as an act of the language communication, points to the communicative function of speech (1988). Thanks to the speech, we can present our own experiences, feelings, needs; we can also influence the behavior of the recipients, encourage them to react. M. Przetacznikowa (1986) uses the term expressive function of speech (expression of experience) and the impressive speech function (impact on the environment), treating them as genetically primary function of language communication. The speech also serves the representational role (symbolic, cognitive) replacing things and pointing out to them. S. Gajda defines this role as sending "consciousness of communicants to the extralinguistic world phenomena" (2003, p.21). This feature allows us to talk about what exists, what we can see, but also about things in the past and future, including those that go beyond the circle of our experience, or things in which we have not participated and what we have not experienced. The speech also serves a very important role in the development of thinking, the formation of intelligence, which itself is conditioned by an appropriate level of cognitive development (Wygotski, 1989). Speech helps us in understanding, describing and changing reality and, above all, allows us to operate in this reality. The multiplicity and importance of the functions which the speech (linguistic communication) plays in human life results in the fact that its disorders can lead to multiple, serious outcomes, causing social, cognitive and emotional consequences eliminating or marginalizing the participation of the individual in different spheres of life. Therefore, a competent speech therapy organization gains significant importance helping individuals at different stages of their life in proper shaping, improvement or regaining verbal communication skills.

\section{Conditions for Development of Speech-language Care}

The creator of the foundations of the Polish system of speech-language care can be B. Dylewski who, as the first, in 1931-1932 created a network of classes for children with speech and voice defects in the schools of Vilnius (Dylewski, 1947/1948). Unfortunately, despite 80 years that have passed so far and numerous attempts that were made, we still have not elaborated a consistent, uniform and effective model of speech-language care. The term itself also happens to be understood in various ways, often narrowing its meaning only to care for children.

G. Jastrzębowska defines speech-language care as "any preventive, diagnostic, therapeutic, instructional and dissemination measures to prevent, reduce or eliminate distortions and disturbances in the communication process and mitigation of 
their effects both in the individual (disturbances in emotional and social functioning etc.) and social (high costs of measures to eliminate this phenomenon, etc.) dimension. (Jastrzębowska, 2003, p.301). Speech-language care, therefore, is an act addressed to all recipients of speech therapy services, allowing for diagnosis and fulfillment of the needs of people with impaired verbal communication, regardless of their age. L. Kaczmarek also interpreted speech therapy in a broad sense including six phases of speech-language care, from prenatal care through the nursery age, preschool, early school, school, to an adult care (Kaczmarek, 1991).

Speech-language care in our country is coordinated by the Ministry of Health and Social Care and the Ministry of Education, which is associated with different rules applicable to different facilities which are subordinate to two ministries. Polish speech-language care system is part of the educational system as well as the health care system (Jastrzębowska, 2003). Not only do facilities providing speech therapy services fall under different ministries, but also speech therapists who are employed there, work under different rules. Lack of uniform legal solutions affects the functioning of speech-language care. Other determinants of speechlanguage care development (except clear-cut and uniform regulatory framework) include:

- proper financial outlays, their appropriate and suitable management according to rationally and accurately identified needs of people with impaired speech and its development,

- properly prepared team of specialists in the field of linguistic communication disorders,

- intensive development of research in the field of speech therapy,

- cooperation of speech therapists, doctors, psychologists, therapists, educators, occupational therapists and other professionals caring for people with impaired linguistic communication,

- cooperation and support for families of people with speech disorders,

- the level of awareness of opportunities to help people with speech disorders and the prevention of speech disorders.

According to G. Jastrzębowska, speech-language care idea is based on the existence of three links:

- highly qualified speech therapists,

- parents of children with speech disorders,

- intermediate link, which includes adequately prepared teachers (2003).

The considerations of the author, who so aptly defines speech-language care, lack consistency. Listing the speech-language care links, she narrows its understanding by focusing on school (preschool) age children ruling out almost automatically adults, neonates, infants and toddlers from the speech-language care group of recipients. If the fact that the subject of speech therapy activities are people with speech disorders in the course of their entire lives is indisputable, we should rather talk about speech therapists on the one hand, and the recipients 
of the speech therapy on the other, which include not only children but also adults with impaired speech and their families. Therefore, the speech-language therapy link can be the nearest and dearest of the people with speech disorders. In the case of an adult - a spouse, partner or adult children. What deserves criticism is also the concept of the existence of an intermediate link in the figure and the teacher who is prepared, as Jastrzębowska writes , ,...) to make a preliminary diagnosis and conduct the therapy of simple defects in articulation..." (2003, p.304). Unfortunately, we often have to deal with such pseudo diagnoses made by unprepared, by the natural course of things, teachers. "Simple speech defects" is a very imprecise and not very sharp notion. What does it actually mean and is the teacher prepared for such an evaluation? This is the question which arises especially from the perspective of speech therapist practice when it turns out that the seemingly ,simple" speech defect is not that simple. Obviously, this does not mean a lack of cooperation of teachers with speech therapists. The idea of an intermediate link is worth developing. The indirect link, in the case of speech-language care for school age / preschool age children, could be the teacher whose role, however, should be different. The teacher should know the correct development of the child's speech, he or she should know what can be disturbing in the development of linguistic communication, and, if so, refer the child and his/her parents to a specialist. The speech therapist and the teachers should work together in the course of therapy as well. The teacher can and should also play an important role in stimulating the development of speech in terms of creating conditions for the onset of abilities development and may also take action for the speech-language pathology prevention. This model of collaboration in the care for children with speech disorders in school / preschool age seems the most reasonable and professional. Such an indirect link can also be a nurse, health visitor or a midwife. This includes care for children from birth through infancy, toddlers, preschool, school to the youth and adults into old age.

Looking closely at socio-demographic changes is of no less importance than determining who and by what means will recognize and fulfill the needs of people with speech disorders. Analysis of those changes will allow for the targeting of speechlanguage care, which will answer the question: who such assistance must be provided to and who will need it. Although the development of a uniform system of speechlanguage care in Poland has failed, it is worth considering which areas should be developed and which speech therapy services will be in the greatest demand.

\section{The Socio-demographic Changes as Determinants in Speech- -language Care}

The end of the twentieth century and the beginning of the twenty first century mark intense socio-demographic changes in Poland. Considering the demographic and social changes that may affect the shape and organization of speech-language 
care and which are the challenge for modern speech therapy, two things should be emphasized. These are:

- increase in the number of elderly people,

- low number of births.

These changes can be described as an aging population (Cicharska, 2009). It generates new social and economic problems, but it also poses new tasks for the health care, social care and speech-language care.

Other observed changes affecting the demand for speech therapy services include the decrease in mortality in people of working age and declining infant mortality (Szatur - Jaworska, 2002). Paradoxically, these phenomena are accompanied by a rise in the occurrence of various diseases the consequence of which may be impaired linguistic communication. Those diseases may include cancers, including cancers of the central nervous system, epithelial tumors of the head and neck (i.e. those of oral cavity, pharynx, larynx or nasal cavity) (Jassem, Kawecki, Krajewski, Krzakowski, Szyfter, 2009; Fijuth, Biernat, Bobek-Billewicz, Glinski, Krajewski, Krzakowski, 2009). These ailments can also include strokes, multiple sclerosis, Alzheimer's disease and Parkinson's disease. The increase in the occurrence of various cancers is confirmed by the Polish Union of Oncology (www. puo.pl). Statistics also show an increase in the occurrence of strokes, especially in the elderly population (Kwolek, 2009). The disease that develops between 40 and 70 years of age and whose occurrence is increased in population over 60 years of age is the Parkinson's disease, resulting in motor, cognitive, emotional, and language deficits. People with Parkinson's disease are diagnosed, inter alia, with reduced verbal fluency, and articulatory difficulties in connection with motor disorders of the speech organs (Osiejuk-Łojek 1997). Multiple sclerosis (MS) is a chronic neurological disease which attacks people in the prime of life, usually between 10 and 49 years of age, which also leads to speech disorders in the form of respiratory-phonatory-articulatory abnormalities. Research confirms that Poland belongs to the regions of the world with the highest occurrence of this disease (Szepietowska, 1997). Alzheimer's disease also belongs to brain degenerative diseases, thus leading to progressive, irreversible and very serious consequences for mental functioning, including linguistic communication disorders. In this situation, the point is to slow down the irreversible changes. As far as this disease is concerned, it affects the elderly, and the probability of its development in people aged over 85 ranges from 25 to $40 \%$ (Domagała, 2008). What is also observed in Poland is a systematic increase in the occurrence of occupational diseases, among which the leading problem includes occupational diseases of the speech organ (Śliwińska - Kowalska, 2001). It confronts the speech-language care with the task of organizing therapy of voice disorders in people who use it in a particular way in their work and who require special vocal predispositions. Such professions include, among other, teachers. Appropriate, early and professional occupational therapy of dysphonia (occupational diseases of speech organs) means, for many 
people, the opportunity to return to a learned profession. In this light, what cannot be underestimated is the postulate to spread knowledge about the rules of proper voice emission as one of the areas of speech-language care functioning. The demand is in line with the maxim that prevention is better than cure.

Another problem that should be included in speech-language care planning is a dynamic development of technological civilization. Its negative consequence is the increase in the number of traffic accidents. This leads to a growing number of cranial cerebral traumas, leading, in turn, to very serious speech disorders (aphasia, dysarthria), which require long-term speech rehabilitation, which still gives a chance to regain lost speech functions.

Advances in medicine allow us to keep the growing number of children that were not previously possible to be saved, alive. The dynamic development of various medical disciplines increases the chances of survival for children with congenital defects in systems and organs, and it also allows us to save children with a history of early stage diseases which may secondarily damage the structure and function of many systems and organs. Since the development of speech is determined by many factors, any irregularities concerning the structure and functioning of the nervous system, visual and hearing organ aberrations, abnormalities in the structure and functioning of the peripheral organs of speech, impaired motor and cognitive development may lead to the emergence of speech disorders. Improved disabled or threatened with disability children survival will, therefore, increase the demand for specialized, interdisciplinary care, including speech-language care. This group can include prematurely born children, especially that less and less mature infants are kept alive. Premature children are at a greater risk of developing various disorders, including disorders of speech. Own studies results confirm that the most common speech disorders developed in premature children include non-spontaneous delayed speech development (NORM) of various etiology. These are the delays resulting from developmental disorders and diseases. They concern numerous aspects of speech, i.e. speaking, understanding, articulatory organs efficiency, breathing and vocal features and they require long-term (many years) speech therapy (Gacka, 2011).

The socio-demographic trends presented here should be included in the planning and organization of speech-language care. The analysis of these trends should draw attention to the speech therapy areas of interest that, in a broader aspect than ever, are to be developed. The areas of speech-language care which gain greater importance in the face of the changes which take place include:

- the impact of early speech therapy intervention,

- the impact aimed at adults (both economically active and those in the old age).

Obviously, this does not mean that the issues connected with helping preschool/school age children and the youth are marginalized. This only means greater attention drawn to the problems of early diagnosis of speech disorders 
in newborn children, infants and toddlers, that is within early intervention. What should be understood by early intervention speech therapy is the influence on the process of development of speech and its modification which refers to children from birth to 3 years of age in whom we see symptoms of speech abnormalities and / or those who are at risk of linguistic communication abnormalities (Gacka, 2012). This also means providing speech-language care to an increasing number of older people and people of working age who will need such care. Care for adults, including the elderly should be developed in two directions. On the one hand, it should be focused on improving disturbed language functions or recovery of lost speech abilities, on the other hand - on preventive measures, especially in the prevention of voice disorders.

\section{Speech-language Care in Terms of Quality of Life}

As it was mentioned before, the need to communicate, with speech being its most perfect form, is one of the basic human needs. Fulfilling this need allows for satisfying and full-sized existence. Speech disorders may lead to an exclusion from social, professional and public life, they may lead to consequences in the emotional and cognitive spheres. Speech disorders may appear at different stages of life. In the case of children, we often deal with problems connected with the formation of proper speech. In adults, the problem usually consists in a total or partial loss of speech or impaired speech ability that has already been formed. Speech disorders in adults, therefore, often (though not exclusively) occur after the proper functioning of the linguistic communication process. This happens in the cases of aphasia, certain forms of dysarthria, dysphonia, loss of ability to communicate after the laryngectomy or in the case of speech disorders related to the Alzheimer's dementia.

According to a classic definition of M. Maruszewski, aphasia is "partial or total disruption of mechanisms responsible for programming speech activities of a human being who has previously mastered these activities, caused by organic damage to the brain structures " (Maruszewski, 1966, p.98). Dysarthria should be understood as respiratory-phonatory-articulatory disorders resulting from damage or dysfunction of cranial nerves and their nuclei in the central nervous system that are responsible for the work of phonatory and articulatory organs (Lewandowski, Tarkowski, 1999). These defects may result from mechanical trauma, stroke, cancerogenesis and progressive, congenital or acquired neurological diseases. Dysphonia is a voice disorder of various etiologies (Pawłowski, 2010).

Since speech plays such important functions in human life, problems with its disorders and its development may lead to grave consequences. The task of speech-language care is to assist in the development of speech or improve / restore 
the ability of linguistic communication, as well as taking measures to prevent the emergence of speech disorders. Speech-language care understood in this way helps improve the quality of life by fulfilling the needs of communication. It facilitates development of communication skills, their improvement or recovery. Contemporary speech therapy, as an interdisciplinary science, draws on the achievements of other sciences, including linguistics and, in particular, cognitive linguistics. It focuses not only on the mechanisms of language disorders, but the individual human being with impaired speech. From this point of view, it is interested in a quality of life for those with impaired linguistic communication. Quality of life is a concept that is interpreted differently by representatives of many disciplines. We use it in philosophy, medicine, psychology or pedagogy, where it is considered from the standpoint of the individual, but also in sociology or economics, where the quality of life of a society is discussed. Without going into detailed theoretical considerations, it can be assumed that the quality of life is the degree to which an individual is happy with life, the extent to which their needs are fulfilled (Dziurowicz - Kozłowska, 2002). Therefore, it also includes the extent to which individual need to communicate with the language, express the judgments, experiences, and feelings is fulfilled. Quality of life concerns the main spheres of human life: physical, psychological and social. Different spheres have different meaning for different people, but every person, as a social being, tends to come to an agreement with another person and the most common way that people communicate with each other is speech. The goal of any speech therapy is not only to aid in the formation of speech, or improvement / restoration of disturbed language functions; equally important is to create a chance of integration or social reintegration. This one of the ways that Pąchalska M. (1999) perceives goals for speech therapy in a patient with aphasia. Reintegration is understood as ".. dynamic activities of the patient and allowing them to develop their potentials regardless of limitations" (Pąchalska, 1999, p.217). This is the way that the role of speech-language therapy should be perceived in the cases of other speech disorders. In this context, considering speech-language care in terms of quality of life seems to be obvious.

\section{References}

Aitchison J. (1991). Ssak, który mówi. Wstęp do psycholingwistyki. Warszawa: PWN.

Chęciek M., Nowakowska - Kempna I. (1996). Z historii logopedii na Śląsku.. Logopedia, 23, p. $57-67$.

Cicharska A. (2009). Przemiany demograficzne w Polsce. Geografia w szkole, 1, s. 5-10.

Demelowa G. (1975). Władysław Ołtuszewski. Logopedia, 12, p. 111- 114.

Domagała A. (2008). Standard postępowania logopedycznego w przypadku zaburzeń mowy w otępieniu alzheimerowskim. Logopedia, 37, p. 297-311.

Dylewski B. Organizacja walki z wadami mowy i głosu. Szkoła Specjalna, 1947/1948, 1-4, p. 35-51.

Dziurowicz- Kozłowska A. (2002). Wokół jakości życia. Psychologia Jakości Życia, T I, 2, p. 77-99. 
Fijuth J., Biernat W., Bobek - Bilewicz B., Gliński B., Krajewski R., Krzakowski M.: (2009). Nowotwory ośrodkowego układu nerwowego [In:] Krzakowski M. [Ed.] Zalecenia postępowania diagnostyczno - terapeutycznego w nowotworach złośliwych. Gdańsk: Via Medica.

Gacka E. Rodzaje i frekwencja zaburzeń rozwoju mowy u dzieci z porodów przedwczesnych. Badania własne. Forum Logopedyczne, 2011 a, 19, p. 65-74.

Gacka E. (2012). Wczesna interwencja logopedyczna [In:] Podstolec A., Węsierska K. [Ed.] W świecie logopedii. Materiały dydaktyczne. Part I. Katowice: Wyd. Uniwersytetu Śląskiego.

Gajda S. (2003). Lingwistyczne podstawy logopedii [In:] Gałkowski T., Jastrzębowska G. [Ed.] Logopedia. Pytania i odpowiedzi. Podręcznik akademicki. Opole: Wyd. Uniwersytetu Opolskiego. p. 11-82.

Grabias S. (2002). Perspektywy opisu zaburzeń mowy [In:] Grabias S. [Ed.] Zaburzenia mowy. Lublin: Wyd. UMCS, p. 11-43.

Jassem J., Kawecki A., Krajewski R., Krakowski M., Składowski K., Szyfter (2009). Nowotwory nabłonkowe głowy i szyi [In:] Krzakowski M. [Ed.] Zalecenia postępowania diagnostyczno terapeutycznego w nowotworach złośliwych. Gdańsk: Via Media.

Jastrzębowska G. (2003), Stan i perspektywy opieki logopedycznej w Polsce [In:] Gałkowski T., Jastrzębowska G. [ Ed.] Logopedia. Pytania i odpowiedzi. Podręcznik akademicki. Opole: Wyd. Uniwersytetu Opolskiego.

Kaczmarek L. (1988). Nasze dziecko uczy się mowy. Lublin: Wydawnictwo Lubelskie.

Kaczmarek L. (1991). Model opieki logopedycznej w Polsce, p. 5-41. Gdańsk: Gdański Związek Logopedów.

Kaczmarek B. Jan Siestrzyński. Logopedia, 1969, nr 8/9, p. 142-145.

Kwolek A. (2009). Rehabilitacja w udarze mózgu. Rzeszów: Wyd. Uniwersytetu Rzeszowskiego.

Lewandowski A., Tarkowski Z. (1999). Dyzartria- definicje, przyczyny, objawy i rodzaje [In:] Tarkowski Z. [Ed.] Dyzartria. Teoria i praktyka. Lublin: Wyd. Fundacji ORATOR..

Maruszewski M. (1966). Afazja. Zagadnienia teorii i praktyki. Warszawa: PWN.

Osiejuk- Łojek E. (1997). Deficyty neuropsychologiczne w chorobie Parkinsona, p. 191-215. [In:] Herzyk A., Kądzielawa D. [Ed.] Związek mózg- zachowanie w ujęciu neuropsychologii klinicznej. Lublin: Wyd UMCS.

Pawłowski Z. (2010). Podstawy foniatrii dla osób duchownych, aktorów, nauczycieli i prawników. Warszawa : Wyd. Salezjańskie.

Pąchalska M. (1999)..Afazjologia. Warszawa- Kraków: Wydawnictwo Naukowe PWN.

Przetacznikowa M. (1986). Wiek przedszkolny [In:] Żebrowska M. [Ed.] Psychologia rozwojowa dzieci i młodzieży. Warszawa: PWN.

Szatur - Jaworska B. (2002). Starzenie się ludności Polski. Gerontologia Polska, nr 10(4), p. 199206.

Szepietowska M. (1997). Zaburzenia w funkcjonowaniu poznawczym chorych na stwardnienie rozsiane [In:] Herzyk A., Kądzielawa D. [ Ed.] Związek mózg-zachowanie w ujęciu neuropsychologii klinicznej. Lublin: Wyd. UMCS.

Śliwińska - Kowalska M. (2001). Choroby narządu głosu jako problem społeczny [In:] Zawodowe choroby narządu głosu u nauczycieli. Profilaktyczne znaczenie nauki emisji głosu. Materiały szkoleniowe. Łódź: Instytut Medycyny Pracy.

Wygotski L. S.: Myślenie i mowa. Warszawa: PWN. 